\title{
Staphylococcus piscifermentans sp. nov., from Fermented Fish in Thailand
}

\author{
SOMBOON TANASUPAWAT, ${ }^{1}$ YASUHIRO HASHIMOTO, ${ }^{2}$ TAKAYUKI EZAKI, ${ }^{2}$ \\ MICHIO KOZAKI, ${ }^{1}$ AND KAZUO KOMAGATA ${ }^{1 *}$ \\ Department of Agricultural Chemistry, Tokyo University of Agriculture, Sakuragaoka 1-1-1, \\ Setagaya-ku, Tokyo 156, ${ }^{1}$ and Gifu University School of Medicine, \\ Tsukasa-machi 40, Gifu 500, ${ }^{2}$ Japan
}

\begin{abstract}
New coagulase-negative staphylococci were isolated from fermented fish in Thailand. These organisms were differentiated from other Staphylococcus species on the basis of DNA relatedness and biochemical characteristics. Staphylococcus piscifermentans sp. nov. is described, and the type strain is strain SK03 (= NRIC 1817 = JCM 6057 = TISTR 824).
\end{abstract}

In studies of lactic acid bacteria isolated from fermented foods in Thailand, a number of lactobacilli and pediococci and a small number of coagulase-negative staphylococci were isolated (28-31). Several staphylococcal strains isolated from fermented fish and soy sauce mash were identified as Staphylococcus carnosus (30), and other strains were not identified. In this paper we describe a new species, Staphylococcus piscifermentans, for these previously unidentified staphylococci.

\section{MATERIALS AND METHODS}

Bacterial strains. Ten strains were isolated from fermented fish in Thailand $(29,30)$. The designations and isolation sources of these strains are shown in Table 1 . The reference strains which we used are shown in Table 2.

Characteristic determinations. In this study, glucose-yeast extract-peptone medium (30) was used as a basal medium. The following characteristics were determined as described previously (29-31): cell and colonial morphology; catalase activity; benzidine test; coagulase activity; hemolysis of horse blood; oxidase, urease, and phosphatase activities; Voges-Proskauer reaction; hydrolysis of Tween 80 , esculin, arginine, and gelatin; lecithovitellin reaction; nitrate reduction; utilization of citrate; oxidation-fermentation test; acid production from carbohydrates; growth in glucoseyeast extract-peptone medium containing sodium acetate and mineral salt broth (30) at different temperatures and $\mathrm{pH}$ values and in the presence of different concentrations of $\mathrm{NaCl}$; and susceptibility to lysozyme (400 and $1,600 \mu \mathrm{g} / \mathrm{ml}$ ), lysostaphin $(200 \mu \mathrm{g} / \mathrm{ml})$, and novobiocin $(1.6$ and $5.0 \mu \mathrm{g} / \mathrm{ml})$. Anaerobic growth was determined in a semisolid thioglycolate medium (Difco Laboratories, Detroit, Mich.). $\beta$-Glucosidase, $\beta$-glucuronidase, and $\beta$-galactosidase activities were tested by using Staphyogram (Terumo Co., Tokyo, Japan). DNA base composition, cellular fatty acid composition, and quinone systems were determined as reported previously $(1,11,20,26,27,33)$. Fluorometric DNA-DNA hybridization in microdilution wells was carried out in $2 \times$ SSC $(1 \times \mathrm{SSC}$ is $0.15 \mathrm{M} \mathrm{NaCl}$ plus $0.015 \mathrm{M}$ trisodium citrate) and a $50 \%$ formamide solution under optimal $\left(37^{\circ} \mathrm{C}\right)$ and

\footnotetext{
* Corresponding author.
}

stringent $\left(45^{\circ} \mathrm{C}\right)$ conditions as described by Ezaki et al. $(5,6)$. Cell wall peptidoglycan was analyzed as described by Komagata and Suzuki (15). Lactic acid was extracted with ether from fermented broth containing $2 \%$ glucose, $1 \%$ yeast extract, $1 \%$ peptone, and mineral salt (30). Isomers of lactic acid were determined enzymatically by using the method of Okada et al. (18).

\section{RESULTS}

Phenotypic characteristics. The characteristics of 10 strains of $S$. piscifermentans are shown in Table 3 .

DNA base composition. The DNA base compositions of $S$. piscifermentans strains ranged from 36.3 to $37.3 \mathrm{~mol} \%$ guanine plus cytosine. These values were within the same range as the values obtained for strains belonging to other Staphylococcus species (Table 2).

DNA homologies. The levels of DNA relatedness between $S$. piscifermentans strains and other Staphylococcus species are shown in Table 2. $S$. piscifermentans $\mathrm{SK} 03^{\mathrm{T}}(\mathrm{T}=$ type strain) exhibited high levels of DNA relatedness (more than $79 \%$ ) with the other strains of this species which we tested and low levels of DNA relatedness (less than 43\%) with strains belonging to other Staphylococcus species.

Cellular fatty acid composition. Five strains of $\boldsymbol{S}$. piscifermentans had a branched-chain anteiso- $\mathrm{C}_{15: 0}$ fatty acid as a major component. Other acids were also found (Table 4). The presence of $\mathrm{C}_{20: 0}$ fatty acid confirmed the classification of these strains in the genus Staphylococcus, as reported previously (30).

Quinone systems. Ten strains of $S$. piscifermentans contained MK -7 as the major component (more than $88 \%$ of the total) and MK- 6 and MK- 8 as minor menaquinones (less than 12\%) (30; this study).

Cell wall peptidoglycan. The peptidoglycan type of strains SK03 ${ }^{\mathrm{T}}$, SK05, SK14, SK16, Ph78, and Ph79L was L-LysGly $_{4-5}$.

Isomer of lactic acid. Strains SK03 ${ }^{\mathrm{T}}$, SK05, SK14, SK16, $\mathrm{Ph} 78$, and $\mathrm{Ph} 79 \mathrm{~L}$ produced DL-lactic acid.

\section{DISCUSSION}

The characteristics of $S$. piscifermentans that differentiate this species from other novobiocin-susceptible staphylococ- 
TABLE 1. Designations and isolation sources of S. piscifermentans strains

\begin{tabular}{lllll}
\hline \multirow{2}{*}{ Strain } & \multicolumn{3}{c}{ Other designations $^{a}$} & \\
\cline { 2 - 4 } & NRIC & JCM & TISTR & Source $^{b}$ \\
\hline SK02 & 1816 & 6056 & 916 & Kung-chom \\
SK03 & $1817^{\mathrm{T}}$ & $6057^{\mathrm{T}}$ & $824^{\mathrm{T}}$ & Kung-chom \\
SK04 & 1818 & 6058 & 825 & Kung-chom \\
SK05 & 1819 & 6059 & 671 & Kung-chom \\
SK14 & 1820 & 6061 & 917 & Pla-ra \\
SK15 & 1821 & 6062 & 676 & Pla-ra \\
SK16 & 1822 & 6063 & 918 & Pla-ra \\
Ph78 & 1823 & 6071 & 827 & Bu-du \\
Ph79S & 1824 & 6072 & 828 & Bu-du \\
Ph79L & 1825 & 6073 & 677 & Bu-du \\
\hline
\end{tabular}

${ }^{a}$ NRIC, NODAI Research Institute Culture Collection, Tokyo University of Agriculture, Tokyo, Japan; JCM, Japan Collection of Microorganisms, RIKEN, Saitama, Japan; TISTR, Thailand Institute of Scientific and Technological Research, Bangkok, Thailand.

${ }^{b}$ Kung-chom is fermented shrimp, pla-ra is fermented fish, and bu-du is fermented fish in liquid form.

cal species are shown in Table 5. S. piscifermentans and $S$. carnosus were isolated from fermented foods (30) and seem to be similar to each other in their determinative characteristics. When the characteristics of these organisms are compared (Table 3), a combination of the urease and $\beta$-glucosidase reactions is useful for separating the two species. However, there are some exceptions in $S$. piscifermentans and $S$. carnosus. For example, 1 of $10 \mathrm{~S}$. piscifermentans strains is urease negative, and 2 of $10 \mathrm{~S}$. carnosus strains are positive. $\beta$-Glucosidase activity, phosphatase activity, esculin hydrolysis, and acid production from melezitose and sucrose are other variable characteristics. Therefore, these characteristics have only relative value for separating the two species. Furthermore, there are some differences between the characteristics of $S$. carnosus given in Bergey's Manual of Systematic Bacteriology (14) and the characteristics in Table 3; namely, the data for phosphatase, urease, $\beta$-glucosidase, and $\beta$-galactosidase activities and acid production from lactose, D-mannitol, D-mannose, D-ribose, and D-trehalose do not coincide. These discrepancies may be explained by the number of strains studied. Determination of levels of DNA relatedness is useful for correct identification of $S$. piscifermentans. The data for cellular fatty acid composition, quinone systems, peptidoglycan type, DNA base composition, and the lactic acid isomer produced support the differentiation of $S$. piscifermentans from the Staphylococcus species described previously $(3,4,7-10,12-14,17$, $19,21-24,30,32$ ).

Description of Staphylococcus piscifermentans sp. nov. Staphylococcus piscifermentans (pis.ci.fer.men'tans. L. n.

TABLE 2. DNA base compositions and levels of DNA relatedness of $S$. piscifermentans and other novobiocin-susceptible Staphylococcus species

\begin{tabular}{|c|c|c|c|c|c|c|}
\hline \multirow{3}{*}{ Strain } & \multirow{3}{*}{$\begin{array}{l}\mathrm{G}+\mathrm{C} \\
\text { content } \\
\text { (mol\%) }\end{array}$} & \multicolumn{4}{|c|}{ \% Similarity with labeled DNA from: } & \multirow{3}{*}{ Reference } \\
\hline & & \multicolumn{2}{|c|}{ Strain SK03 ${ }^{\mathrm{T}}$} & \multirow{2}{*}{$\begin{array}{c}\text { Strain } \mathrm{Ph} 78 \\
\text { at } 45^{\circ} \mathrm{C}\end{array}$} & \multirow{2}{*}{$\begin{array}{l}\text { Strain } \mathrm{Ph} 79 \mathrm{~L} \\
\quad \text { at } 45^{\circ} \mathrm{C}\end{array}$} & \\
\hline & & $37^{\circ} \mathrm{C}$ & $45^{\circ} \mathrm{C}$ & & & \\
\hline S. piscifermentans $\mathrm{SK} 03^{\mathrm{T}}$ & 36.8 & 100 & 100 & 114 & 93 & \\
\hline S. piscifermentans SK14 & 37.3 & 107 & 102 & 91 & 95 & \\
\hline S. piscifermentans SK02 & 37 & 99 & 88 & $-\bar{b}$ & 116 & \\
\hline S. piscifermentans SK04 & 37 & 99 & 84 & 103 & 81 & \\
\hline S. piscifermentans SK15 & 37.2 & 91 & 89 & 83 & 77 & \\
\hline S. piscifermentans $\mathrm{Ph} 79 \mathrm{~S}$ & 37 & 90 & 70 & 102 & - & \\
\hline S. piscifermentans SK05 & 36.7 & 80 & 66 & 106 & 93 & \\
\hline S. piscifermentans $\mathrm{Ph} 79 \mathrm{~L}$ & 37.1 & 79 & 65 & 110 & 100 & \\
\hline S. piscifermentans SK16 & 36.3 & 79 & 79 & 80 & 80 & \\
\hline S. piscifermentans $\mathrm{Ph} 78$ & 36.4 & - & - & 100 & 88 & \\
\hline S. aureus subsp. anaerobius GIFU $10707^{\mathrm{T} c}$ & 31.7 & 16 & - & - & - & 2 \\
\hline S. aureus subsp. aureus GIFU $9120^{\mathrm{T}}$ & 31.2 & 25 & - & - & - & 25 \\
\hline S. auricularis GIFU $10395^{\mathrm{T}}$ & 38.8 & 17 & - & - & 11 & 13 \\
\hline S. capitis GIFU $9121^{\mathrm{T}}$ & 35.5 & 15 & - & - & - & 12 \\
\hline S. caprae GIFU $10757^{\mathrm{T}}$ & 36.1 & 23 & - & - & 17 & 4 \\
\hline S. carnosus GIFU $10766^{\mathrm{T}}$ & 36 & 43 & - & - & 37 & 21 \\
\hline S. caseolyticus GIFU 10760 & 39 & 10 & - & - & - & 23 \\
\hline S. chromogenes GIFU $12240^{\mathrm{T}}$ & - & 14 & - & - & 7 & \\
\hline S. delphini GIFU $12159^{\mathrm{T}}$ & 39 & 1 & - & - & 6 & 32 \\
\hline S. epidermidis GIFU $8656^{\mathrm{T}}$ & 33.5 & 13 & - & - & - & 30 \\
\hline S. felis GIFU $12627^{\mathrm{T}}$ & 35.2 & 8 & - & - & 4 & 10 \\
\hline S. haemolyticus GIFU $9124^{\mathrm{T}}$ & 36.4 & 5 & - & - & - & 24 \\
\hline S. hominis GIFU $9125^{\mathrm{T}}$ & 33.7 & 1 & - & - & - & 12 \\
\hline S. hyicus GIFU 9843 & - & 4 & - & - & - & \\
\hline S. intermedius GIFU $8781^{\mathrm{T}}$ & 33.5 & 5 & - & - & - & 8 \\
\hline S. lugdunensis GIFU $11876^{\mathrm{T}}$ & 32 & 15 & - & - & 19 & 7 \\
\hline S. schleiferi GIFU $12245^{\mathrm{T}}$ & 37 & 19 & - & - & 17 & 7 \\
\hline S. simulans GIFU $9127^{\mathrm{T}}$ & 34 & 12 & - & - & 7 & 12 \\
\hline S. warneri GIFU $9128^{\mathrm{T}}$ & 34.2 & 19 & - & - & - & 12 \\
\hline
\end{tabular}

${ }^{a}$ DNA base composition data for strains other than $S$. piscifermentans strains were obtained from references.

${ }^{b}-$, not determined.

${ }^{c}$ GIFU, Department of Microbiology, Gifu University School of Medicine, Gifu, Japan. 
TABLE 3. Characteristics of $S$. piscifermentans and $S$. carnosus

\begin{tabular}{|c|c|c|c|}
\hline \multirow[b]{2}{*}{ Characteristic } & \multicolumn{2}{|c|}{ S. piscifermentans } & \multirow{2}{*}{$\begin{array}{l}\text { S. carnosus } \\
(10 \text { strains })^{a}\end{array}$} \\
\hline & $\begin{array}{c}\text { Ten } \\
\text { strains }\end{array}$ & $\begin{array}{l}\text { Strain } \mathrm{SK}^{\mathrm{S}} 03^{\mathrm{T}} \\
\text { reaction }\end{array}$ & \\
\hline Catalase activity & $10^{b}$ & + & $10^{b}$ \\
\hline Coagulase activity & 0 & - & 0 \\
\hline Hemolysis of blood & 0 & - & 0 \\
\hline $\begin{array}{l}\text { Anaerobic growth in thio- } \\
\text { glycolate medium }\end{array}$ & 10 & + & $10^{c}$ \\
\hline Benzidine test & 10 & + & 10 \\
\hline Voges-Proskauer reaction & 0 & - & 0 \\
\hline Oxidase activity & 0 & - & 0 \\
\hline Phosphatase activity & 10 & + & 4 \\
\hline Urease activity & 9 & + & 2 \\
\hline$\beta$-Glucosidase activity & 10 & + & $2^{c}$ \\
\hline$\beta$-Glucuronidase activity & 0 & - & $0^{c}$ \\
\hline$\beta$-Galactosidase activity & 0 & - & $0^{c}$ \\
\hline Nitrate reduction & 10 & + & 10 \\
\hline \multicolumn{4}{|l|}{ Hydrolysis of: } \\
\hline Gelatin & 0 & - & 0 \\
\hline Arginine & 10 & + & 10 \\
\hline Tween 80 & 6 & + & 2 \\
\hline Esculin & 9 & + & 2 \\
\hline \multicolumn{4}{|l|}{$\begin{array}{l}\text { Acid produced aerobically } \\
\text { from: }\end{array}$} \\
\hline D-Arabinose & 0 & - & 0 \\
\hline D-Cellobiose & 0 & - & 0 \\
\hline D-Fructose & 10 & + & 10 \\
\hline L-Fucose & 0 & - & 0 \\
\hline D-Galactose & 6 & + & 1 \\
\hline Gluconate & 0 & - & 0 \\
\hline D-Glucose & 10 & + & 10 \\
\hline Glycerol & 4 & - & 2 \\
\hline Lactose & 6 & + & 1 \\
\hline Maltose & 5 & + & 0 \\
\hline D-Mannitol & 3 & - & 2 \\
\hline D-Mannose & 0 & - & 4 \\
\hline D-Melezitose & 6 & + & 0 \\
\hline Raffinose & 0 & - & $0^{c}$ \\
\hline D-Ribose & 3 & - & $3^{c}$ \\
\hline Salicin & 4 & - & $0^{c}$ \\
\hline Sucrose & 6 & + & 0 \\
\hline D-Sorbitol & 3 & - & 3 \\
\hline D-Trehalose & 10 & + & 10 \\
\hline D-Turanose & 0 & - & 0 \\
\hline Xylitol & 0 & - & 0 \\
\hline D-Xylose & 0 & - & 0 \\
\hline $\begin{array}{l}\text { Growth in the presence } \\
\text { of } 15 \% \mathrm{NaCl}\end{array}$ & 10 & + & 9 \\
\hline $\begin{array}{l}\text { Lysostaphin resistance } \\
(200 \mu \mathrm{g} / \mathrm{ml})\end{array}$ & 0 & - & 0 \\
\hline $\begin{array}{l}\text { Lysozyme resistance } \\
\qquad(400 \mu \mathrm{g} / \mathrm{ml})\end{array}$ & 8 & + & 8 \\
\hline $\begin{array}{l}\text { Novobiocin resistance } \\
\quad(1.6 \mu \mathrm{g} / \mathrm{ml})\end{array}$ & 0 & - & 0 \\
\hline
\end{tabular}

${ }^{a}$ Data from reference 30.

${ }^{b}$ Number of strains positive.

${ }^{c}$ Unpublished data.

piscis, fish; M.L. part.adj. fermentans, fermenting; M.L. adj. piscifermentans, fish fermenting). Cells are gram-positive cocci (diameter, $1.0 \mu \mathrm{m}$ ) that are nonmotile and nonsporeforming and occur singly, in pairs, in tetrads, and in clusters. Colonies on glucose-yeast extract-peptone agar are usually opaque, circular, low convex with entire margins, and nonpigmented or white with a yellowish orange tint. They are positive for catalase activity, the benzidine test, nitrate reduction, phosphatase activity, $\beta$-glucosidase activ-
TABLE 4. Cellular fatty acid composition of $S$. piscifermentans

\begin{tabular}{|c|c|c|}
\hline \multirow{2}{*}{ Fatty acid } & \multicolumn{2}{|c|}{$\%$ of total in $S$. piscifermentans } \\
\hline & Five strains & Strain SK $03^{\mathrm{T}}$ \\
\hline Iso- $\mathrm{C}_{14: 0}$ & 1.3 & 2 \\
\hline $\mathrm{C}_{14: 0}$ & 0.9 & 1 \\
\hline Iso- $\mathrm{C}_{15: 0}$ & 6 & 10 \\
\hline Anteiso- $\mathrm{C}_{15: 0}$ & 35 & 28 \\
\hline $\mathrm{C}_{15: 0}$ & 0.3 & $-^{a}$ \\
\hline Iso-C $\mathrm{C}_{16: 0}$ & 0.4 & 1 \\
\hline$C_{16: 0}$ & 4.8 & 6 \\
\hline Iso- $C_{17: 0}$ & 2 & 2 \\
\hline Anteiso- $\mathrm{C}_{17: 0}$ & 6.7 & 3 \\
\hline $\mathrm{C}_{18: 0}$ & 16.9 & 18 \\
\hline Iso-C $\mathrm{C}_{19: 0}$ & 1.2 & 1 \\
\hline Anteiso- $\mathrm{C}_{19: 0}$ & 2.8 & 1 \\
\hline $\mathrm{C}_{20: 0}$ & 18.5 & 24 \\
\hline Unknown & 1.5 & 1.7 \\
\hline
\end{tabular}

ity, and arginine hydrolysis and negative for coagulase activity, hemolysis of horse blood, oxidase activity, the Voges-Proskauer reaction, the lecithovitellin reaction, gelatin hydrolysis, citrate utilization, $\beta$-glucuronidase activity and $\beta$-galactosidase activity. Most strains are positive for hydrolysis of urea, Tween 80 , and esculin. All are facultatively anaerobic and split glucose fermentatively. Acid is produced aerobically from D-glucose, D-fructose, and D-trehalose, but not from D-arabinose, D-cellobiose, L-fucose, gluconate, D-mannose, raffinose, D-turanose, D-xylose, and xylitol. Compounds which give variable acid production are shown in Table 3.

The strains grow in thioglycolate medium, grow at 18 and $42^{\circ} \mathrm{C}$, and grow well between $\mathrm{pH} 6.8$ and 9.0. All strains grow weakly at $\mathrm{pH} 5.0$ but not at $\mathrm{pH} 4.5$ and at $45^{\circ} \mathrm{C}$. All strains grow in medium containing 6,8 , or $10 \% \mathrm{NaCl}$, and some strains grow in medium containing $15 \% \mathrm{NaCl}$. Susceptible to lysostaphin $(200 \mu \mathrm{g} / \mathrm{ml})$ and novobiocin $(1.6$ and 5.0 $\mu \mathrm{g} / \mathrm{ml}$ ). Most strains are resistant to lysozyme (400 and 1,600 $\mu \mathrm{g} / \mathrm{ml}$ ). Variable characteristics are shown in Table 3.

The DNA base composition ranges from 36.3 to $37.3 \mathrm{~mol} \%$ guanine plus cytosine. The strains contain anteiso- $\mathrm{C}_{15: 0}$ fatty acid as a dominant fatty acid. MK-7 is the major menaquinone, and MK-6 and MK-8 are minor menaquinones. The strains tested contain peptidoglycan of the L-Lys-Gly ${ }_{4-5}$ type and produce DL lactic acid from glucose. The strains were isolated from kung-chom (fermented shrimp), pla-ra (fermented fish), and bu-du (fermented fish in liquid form). Strain SK03 (= NRIC 1817 = JCM 6057 = TISTR 824) is the type strain and was isolated from kung-chom.

Description of the type strain. Type strain SK03 has the characteristics given above in the description of the species. The guanine-plus-cytosine content of strain SK03 ${ }^{\mathrm{T}}$ DNA is $36.8 \mathrm{~mol} \%$ (as determined by high-performance liquid chromatography).

\section{ACKNOWLEDGMENTS}

We thank J. Sugiyama, Institute of Applied Microbiology, The University of Tokyo, Tokyo, Japan, for the Latin etymology and K. Suzuki, Japan Collection of Microorganisms, RIKEN, Wako-shi, Saitama, Japan, for helping with the analysis of cellular fatty acids and cell wall peptidoglycan. 


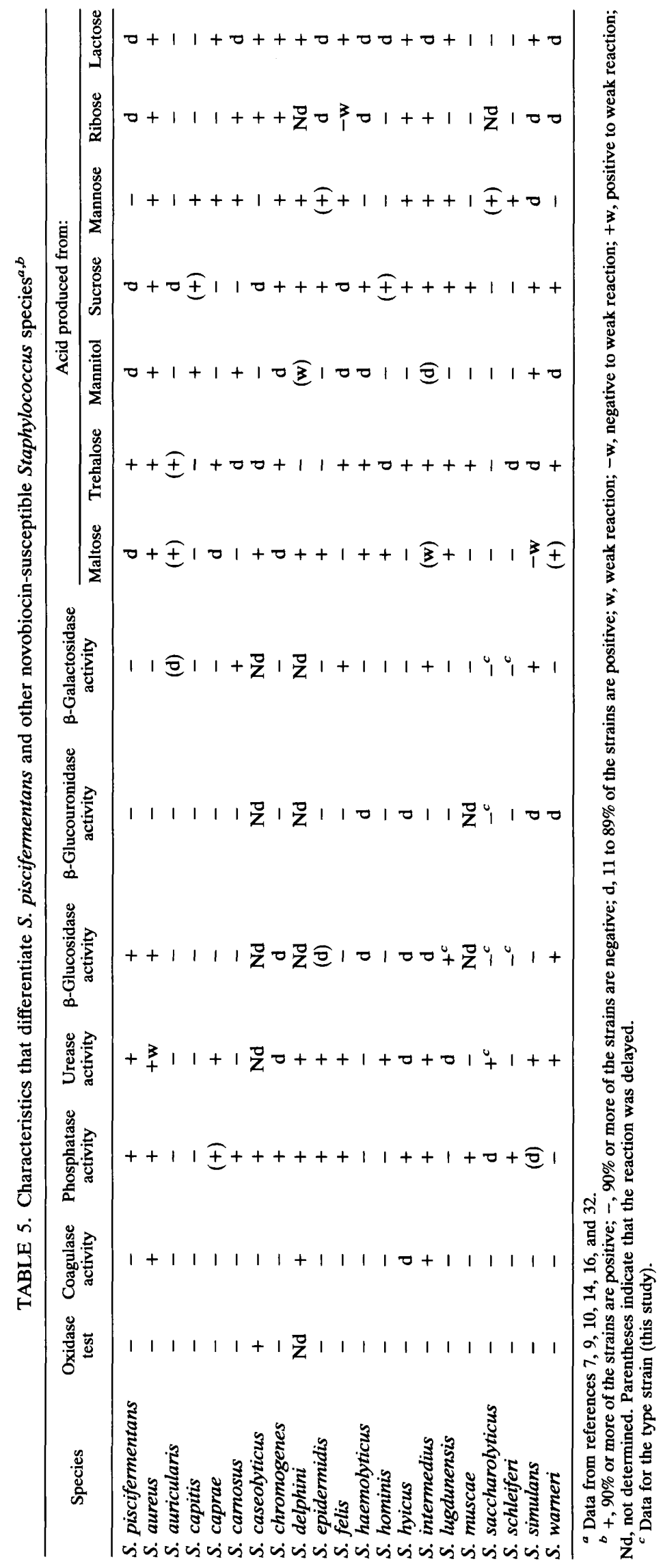




\section{REFERENCES}

1. Collins, M. D., T. Pirouz, M. Goodfellow, and D. E. Minnikin. 1977. Distribution of menaquinones in actinomycetes and corynebacteria. J. Gen. Microbiol. 100:221-230.

2. De La Fuente, R., G. Suarez, and K. H. Schleifer. 1985. Staphylococcus aureus subsp. anaerobius subsp. nov., the causal agent of abscess disease of sheep. Int. J. Syst. Bacteriol. 35:99-102.

3. Devriese, L. A., V. Hájek, P. Oeding, S. A. Meyer, and K. H. Schleifer. 1978. Staphylococcus hyicus (Sompolinsky 1953) comb. nov. and Staphylococcus hyicus subsp. chromogenes subsp. nov. Int. J. Syst. Bacteriol. 28:482-490.

4. Devriese, L. A., B. Poutrel, R. Kilpper-Bälz, and K. H. Schleifer. 1983. Staphylococcus gallinarum and Staphylococcus caprae, two new species from animals. Int. J. Syst. Bacteriol. 33:480486.

5. Ezaki, T., Y. Hashimoto, N. Takeuchi, H. Yamamoto, S. Liu, H. Miura, K. Matsui, and E. Yabuuchi. 1988. Simple genetic method to identify viridans group streptococci by colorimetric dot hybridization and fluorometric hybridization in microdilution wells. J. Clin. Microbiol. 26:1708-1713.

6. Ezaki, T., Y. Hashimoto, and E. Yabuuchi. 1989. Fluorometric DNA-DNA hybridization in microdilution wells as an alternative to membrane filter hybridization in which radioisotopes are used to determine genetic relatedness among bacterial strains. Int. J. Syst. Bacteriol. 39:224-229.

7. Freney, J., Y. Brun, M. Bes, H. Meugnier, F. Grimont, P. A. D. Grimont, C. Nervi, and J. Fleurette. 1988. Staphylococcus lugdunensis sp. nov. and Staphylococcus schleiferi sp. nov., two species from human clinical specimens. Int. J. Syst. Bacteriol. 38:168-172.

8. Hájek, V. 1976. Staphylococcus intermedius, a new species isolated from animals. Int. J. Syst. Bacteriol. 26:401-408.

9. Hájek, V., W. Ludwig, K. H. Schleifer, N. Springer, W. Zitzelsberger, R. M. Kroppenstedt, and M. Kocur. 1992. Staphylococcus muscae, a new species isolated from flies. Int. J. Syst. Bacteriol. 42:97-101.

10. Igimi, S., S. Kawamura, E. Takahashi, and T. Mitsuoka. 1989. Staphylococcus felis, a new species from clinical specimens from cats. Int. J. Syst. Bacteriol. 39:373-377.

11. Ikemoto, S., K. Katoh, and K. Komagata. 1978. Cellular fatty acid composition in methanol-utilizing bacteria. J. Gen. Appl. Microbiol. 24:41-49.

12. Kloos, W. E., and K. H. Schleifer. 1975. Isolation and characterization of staphylococci from human skin. II. Descriptions of four new species: Staphylococcus warneri, Staphylococcus capitis, Staphylococcus hominis, and Staphylococcus simulans. Int. J. Syst. Bacteriol. 25:62-79.

13. Kloos, W. E., and K. H. Schleifer. 1983. Staphylococcus auricularis sp. nov.: an inhabitant of the human external ear. Int. J. Syst. Bacteriol. 33:9-14.

14. Kloos, W. E., and K. H. Schleifer. 1986. Genus IV. Staphylococcus Rosenbach 1884, 18 (Nom. Cons. Opin. 17 Jud. Comm. 1958, 153), p. 1013-1035. In P. H. A. Sneath, N. S. Mair, M. E. Sharpe, and J. G. Holt (ed.), Bergey's manual of systematic bacteriology, vol. 2. The Williams \& Wilkins Co., Baltimore.

15. Komagata, K., and K. Suzuki. 1987. Lipid and cell-wall analysis in bacterial systematics. Methods Microbiol. 19:161-207.

16. Lennette, E. H., A. Balows, W. J. Hausler, Jr., and H. J. Shadomy (ed.). 1985. Manual of clinical microbiology, 4th ed. American Society for Microbiology, Washington, D. C.

17. Nahaie, M. R., M. Goodfellow, D. E. Minnikin, and V. Hájek.
1984. Polar lipid and isoprenoid quinone composition in the classification of Staphylococcus. J. Gen. Microbiol. 130:24272437.

18. Okada, S., T. Toyoda, and M. Kozaki. 1978. An easy method for the determination of the optical types of lactic acid produced by lactic acid bacteria. Agric. Biol. Chem. 42:1781-1783.

19. O'Leary, W. M., and S. G. Wilkinson. 1988. Gram-positive bacteria, p. 117-201. In C. Ratledge, and S. G. Wilkinson (ed.), Microbial lipids, vol. 1. Academic Press, Ltd., London.

20. Saito, H., and K. Miura. 1963. Preparation of transforming deoxyribonucleic acid by phenol treatment. Biochim. Biophys. Acta 72:619-629.

21. Schleifer, K. H., and U. Fischer. 1982. Description of a new species of the genus Staphylococcus: Staphylococcus camosus. Int. J. Syst. Bacteriol. 32:153-156.

22. Schleifer, K. H., R. Kilpper-Bälz, and L. A. Devriese. 1984 Staphylococcus arlettae sp. nov., $S$. equorum sp. nov. and $S$. kloosii sp. nov.: three new coagulase-negative, novobiocinresistant species from animals. Syst. Appl. Microbiol. 5:501509.

23. Schleifer, K. H., R. Kilpper-Bälz, U. Fischer, A. Faller, and J. Endl. 1982. Identification of "Micrococcus candidus" ATCC 14852 as a strain of Staphylococcus epidermidis and of "Micrococcus caseolyticus" ATCC 13548 and Micrococcus varians ATCC 29750 as members of a new species, Staphylococcus caseolyticus. Int. J. Bacteriol. 32:15-20.

24. Schleifer, K. H., and W. E. Kloos. 1975. Isolation and characterization of staphylococci from human skin. I. Amended descriptions of Staphylococcus epidermidis and Staphylococcus saprophyticus and descriptions of three new species: Staphylococcus cohnii, Staphylococcus haemolyticus, and Staphylococcus xylosus. Int. J. Syst. Bacteriol. 25:50-61.

25. Silvestri, L. G., and L. R. Hill. 1965. Agreement between DNA base composition and taxonometric classification of gram-positive cocci. J. Bacteriol. 90:136-140.

26. Tamaoka, J., Y. Katayama-Fujimura, and H. Kuraishi. 1983. Analysis of bacterial menaquinone mixtures by high performance liquid chromatography. J. Appl. Bacteriol. 54:31-36.

27. Tamaoka, J., and K. Komagata. 1984. Determination of DNA base composition by reverse-phase high-performance liquid chromatography. FEMS Microbiol. Lett. 25:125-128.

28. Tanasupawat, S. 1984. Lactic acid bacteria found in fermented tea leaves, Miang. J. Grad. School Chulalongkorn Univ. 5:84 92. (In Thai.)

29. Tanasupawat, S., and W. Daengsubha. 1983. Pediococcus species and related bacteria found in fermented foods and related materials in Thailand. J. Gen. Appl. Microbiol. 29:487-506.

30. Tanasupawat, S., Y. Hashimoto, T. Ezaki, M. Kozaki, and K. Komagata. 1991. Identification of Staphylococcus carnosus strains from fermented fish and soy sauce mash. J. Gen. Appl. Microbiol. 37:479-494.

31. Tanasupawat, S., and K. Komagata. 1988. DNA base composition, quinone systems, and cellular fatty acid composition of strains in Pediococcus species. Bull. Jpn. Federation Culture Collect. 4:63-67.

32. Varaldo, P. E., R. Kilpper-Bälz, F. Biavasco, G. Satta, and K. H. Schleifer. 1988. Staphylococcus delphini sp. nov., a coagulasepositive species isolated from dolphins. Int. J. Syst. Bacteriol. 38:436-439.

33. Yamada, K., and K. Komagata. 1970. Taxonomic studies on coryneform bacteria. III. DNA base composition of coryneform bacteria. J. Gen. Appl. Microbiol. 16:215-224. 